\title{
Observations on Reproductive Activity Among Female Bandicota bengalensis in Rangoon ${ }^{1}$
}

\author{
Dan W. WALTON, J. E. BROOKS, U Maung Maung TUN \\ \& U Hla NAING
}

\begin{abstract}
D.W. Walton, J. E. Brooks, U Maung Maung Tun \& U Hla Naing, 1978: Observations on reproductive activity among female Bandicota bengalensis in Rangoon. Acta theriol., 23, 33: 489-501 [With 2 Figs. \& 7 Tables].

Observations on reproduction among female lesser bandicoots (Bandicota bengalensis) in Rangoon are presented. It was found that among non-pregnant females, a sharp increase in body weight relative to head and body length occurred at a head and body length of about $160 \mathrm{~mm}$. Pregnancy was first noted among those rats at about the same size and the increase in body weight is thought to be closely related to sexual maturation. The $50 \%$ point for the opening of the vaginal orifice occurred at a head and body length of $132 \mathrm{~mm}$. Lactation was not noted in females below a head and body length of $180 \mathrm{~mm}$. The average embryo count was 7.4 per pregnant female with a range of 1-14 embryos. The mammary pattern was highly variable and asymmetrical. Evidence for post-partum estrus and breeding was not clear although these phenomena may be of seasonal importance. P'acental scar data indicates that the lesser bandicoot population in Rangoon is maintained by the production of one to two litters per breeding female during her lifetime. Although reproductively active throughout the study period, a period of hightened activity was observed during the dry season, November - April.

[Rodent Control Demonstration Unit, WHO, P.O. Box 14, Rangoon, Burma].
\end{abstract}

\section{INTRODUCTION}

The lesser bandicoot rat, Bandicota bengalensis is widely distributed across Southern Asia (E 11 e r m a n, 1961). Although frequently described as a field rat in earlier writings, this species has become a close urban commensal of man within the past 70 years, taking its place as a pest

1 The work of the Rodent Control Demonstration Unit is supported by a grant from the Government of Denmark (DANIDA) to the World Health Organization which is gratefully acknowledged. 
rodent of primary importance. In the rapidly expanding cities of India, such as Bombay, New Delhi, Madras and Calcutta, its relative prevalence as a member of the urban small mammal fauna has increased at the expense of Rattus rattus and $R$. norvegicus (D e or as, 1969; S e a l \& B a n e r ji, 1969). Its presence and abundance in Rangoon was well documented by Harrison \& Woodville (1948).

The species is a pest by virtue of its vigorous burrowing habits and the enormous soil mounds it throws up, frequently blocking storm gutters and drains and causing the collapse of building foundations, streets and sidewalks. The lesser bandicoot frequents grain storage facilities, food shops, restaurants, markets and homes. In grain storage facilities and food shops, bandicoots consume and contaminate large quantities of human foods. It is also of considerable public health importance because of its association with plague. $B$. bengalensis has been found susceptible to Yersinia pestis infection and isolates of this organism have been made from the lesser bandicoot in several areas in India ( $\mathrm{B} \mathrm{h}$ a t $\mathrm{n}$ a g a $\mathrm{r}, 1966$ ). A high prevalence of antibodies to $\mathrm{Y}$. pestis recently has been detected among $B$. bengalensis in Rangoon $(\mathrm{Brooks}$ et al., 1977).

Studies on the biology and behaviour of $B$. bengalensis are rare and are summarized by Spillet (1968) and Frantz (1973). Recent observations on this species were made as part of a survey of the small mammal fauna of the city of Rangoon. These studies were made by the Rodent Control Demonstration Unit of the World Health Organization in cooperation with the Ministry of Health of the Socialist Republic of the Union of Burma. Studies of reproduction in a species are necessary in order to understand its role in population changes. Since virtually the only published data on reproduction in B. bengalensis is that of $\mathrm{Spille}$ t (1968), this report will deal with observations on reproduction among female bandicoots in Rangoon.

\section{MATERIALS AND METHODS}

Bandicoots were collected from all parts of the city of Rangoon. They were captured in locally-made wooden live-traps, usually baited with dried fish. Captured animals were brought to the laboratory while still in the traps. There they were anesthetized, bled by cardiac puncture and cambed for ectoparasites. Individual $B$. bengalensis were sexed, measured and weighed. All measurements are given in millimeters and weight in grams. Body weight was obtained by means of either a Pesola or Ohaus spring scale. Reproductive condition was noted on all females: perforation of the vaginal orifice, location and number of visible mammaries, lactation, visible pregnancy and number of embryos. A sample was examined for placental scars. Collections covered every month from September 1975 to December 1976 and comprised a total of 826 female bandicoots. 


\section{RESULTS}

The females were separated into $10 \mathrm{~mm}$ head and body length classes. Weights for those animals in each head and body length class were recorded and the mean and standard deviation calculated. Linear regression lines were then calculated. It can be seen from Figure 1 that the size-weight relationship was not constant and that at a head and body length of approximately $160 \mathrm{~mm}$ there was a sharp increase in weight.

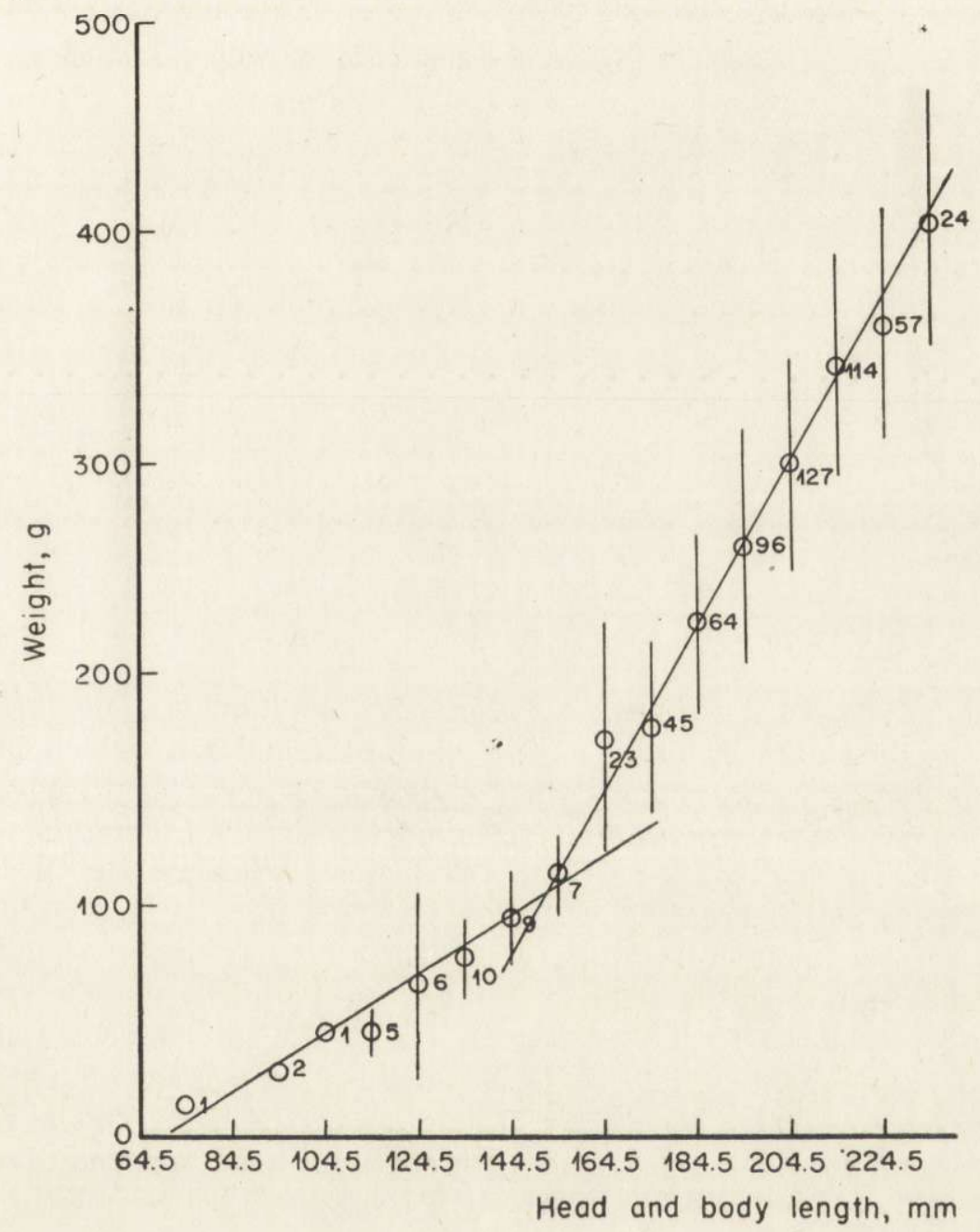

Fig. 1. Relationship of weight to head and body length among non-pregnant female lesser bandicoot rats.

Circles represent mean weight, vertical lines \pm one standard deviation and numbers within the figure the sample size for each point. 
The opening of the vaginal orifice is one of the earliest signs of approaching sexual maturation. A summary of the observations on perforation of the vaginal orifice is presented in Table 1. From those data shown, the $50 \%$ point for this event was found to occur at a head and body length of $132 \mathrm{~mm}$.

Table 1

Summary of observations on perforation of the vaginal orifice in female $B$. bengalensis.

\begin{tabular}{crcc}
\hline H \& B & Sample & No. with vagina open & $\%$ with vagina open \\
\hline $70-79$ & 1 & 0 & 0 \\
$80-89$ & 0 & - & 0 \\
$90-99$ & 2 & 0 & 0 \\
$100-109$ & 1 & 3 & 60.0 \\
$110-119$ & 5 & 1 & 20.0 \\
$120-129$ & 5 & 6 & 60.0 \\
$130-139$ & 10 & 6 & 66.7 \\
$140-149$ & 9 & 7 & 100.0 \\
$150-159$ & 7 & 23 & 92.0 \\
$160-169$ & 25 & 44 & 91.7 \\
$170-179$ & 48 & 75 & 96.2 \\
$180-189$ & 78 & 134 & 99.3 \\
$190-199$ & 135 & 183 & 100.0 \\
$200-209$ & 183 & 165 & 100.0 \\
$210-219$ & 165 & 92 & 100.0 \\
$220-229$ & 92 & 41 & 100.0 \\
$230-239$ & 41 & 10 & 96.7 \\
24 -249 & 10 & 790 & \\
Total \& Average & 817 & & \\
\hline
\end{tabular}

A summary of observations on pregnancy, lactation and number of embryos is presented in Table 2. The smallest females in which pregnancy was observed were found in the head and body length class of $160-169 \mathrm{~mm}$. Lactation was first observed in females in the 180-189 head and body length class. Of the 785 females examined in the size groups where active breeding was observed (160 mm or larger) $40.5 \%$ were either pregnant or lactating. Only $5.8 \%$ of all females examined were both pregnant and lactating.

Table 3 presents a frequency distribution of the number of embryos observed in pregnant female $B$. bengalensis. The average number of embryos per pregnant female was found to be $7.4 \pm 2.4$. The average number of embryos increased with an increase in head and body length of the females (Table 2). The correlation coefficient between head and body length and number of embryos was 0.86 .

Adult female $B$. bengalensis have been stated to have from 12 to 20 mamrnae usually not regularly grouped as they are in Rattus species (Harrison \& Woodville, 1948; 1949). We noted also during the 
study, that the number of conspicuous mammae (those seen without removal of the ventral pelage) was highly variable and that this character might well be used to aid in establishing the size at which sexual maturity occurred. A summary of observations on 817 female $B$. bengalensis is presented in Table 4. These data should be compared with those on pregnancy and lactation given in Table 2 . It can be seen, how-

Table 2

Summary of observations on pregnancy, lactation and number of embryos in female $B$. bengalensis.

\begin{tabular}{|c|c|c|c|c|c|c|c|c|c|}
\hline 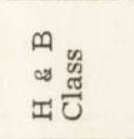 & 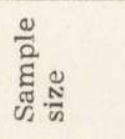 & 完 & बe & 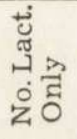 & 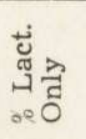 & 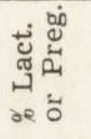 & 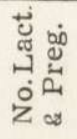 & 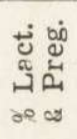 & 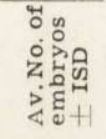 \\
\hline $60-69$ & - & - & - & - & - & $\ldots$ & - & - & - \\
\hline $70-79$ & 1 & - & - & - & - & - & - & - & - \\
\hline $80-89$ & - & - & - & - & $\ldots$ & - & - & - & - \\
\hline $90-99$ & 2 & - & - & - & - & - & - & - & - \\
\hline $100-109$ & 1 & - & - & - & - & - & - & - & - \\
\hline $110-119$ & 5 & - & - & - & - & - & - & - & - \\
\hline $120-129$ & 6 & - & - & - & - & - & - & - & - \\
\hline $130-139$ & 10 & - & - & - & - & - & - & - & - \\
\hline $140-149$ & 9 & - & - & - & - & - & - & - & - \\
\hline $150-159$ & 7 & - & - & - & - & - & - & - & - \\
\hline $160-169$ & 25 & 2 & 8.0 & - & - & 8.0 & - & - & $7.0 \pm 4.2$ \\
\hline $170-179$ & 48 & 3 & 6.3 & - & - & 6.3 & - & - & $6.7 \pm 2.3$ \\
\hline $180-189$ & 78 & 14 & 17.9 & 2 & 2.6 & 20.5 & 2 & 2.6 & $6.1 \pm 1.5$ \\
\hline $190-199$ & 135 & 39 & 28.9 & 16 & 11.9 & 40.8 & 4 & 3.0 & $6.9 \pm 2.2$ \\
\hline $200-209$ & 184 & 57 & 31.0 & 28 & 15.2 & 46.2 & 18 & 9.8 & $7.4 \pm 2.2$ \\
\hline $210-219$ & 167 & 53 & 31.7 & 26 & 15.6 & 47.3 & 13 & 1.8 & $7.5 \pm 2.6$ \\
\hline $220-229$ & 93 & 36 & 38.7 & 13 & 14.0 & 52.7 & 9 & 9.7 & $7.3 \pm 2.2$ \\
\hline $230-239$ & 42 & 18 & 42.9 & 4 & 9.5 & 53.4 & 2 & 4.8 & $8.7 \pm 2.6$ \\
\hline $240-249$ & 10 & 4 & 40.0 & 2 & 20.0 & 60.0 & 0 & 0 & $8.7 \pm 1.5$ \\
\hline $250-259$ & 3 & 1 & 33.3 & 0 & 0 & 33.3 & 0 & 0 & 11 \\
\hline Average & & & & & & & & & \\
\hline \& Total & 826 & 227 & 27.5 & 91 & 11.0 & 38.5 & 48 & 5.8 & $7.4 \pm 2.4$ \\
\hline
\end{tabular}

ever, that the number of conspicuous mammae among the larger sized females ranged from $0-22$. One multiparous female had only 7 conspicuous mammae ( 3 left and 4 right). The mean of 16 is approached by females beginning in the $190-199 \mathrm{~mm}$ head and body size class.

A sample of 460 female $B$. bengalensis was examined for the presence of placental scars. The number of sets of scars recorded was empirically based on an average litter size of eight. A summary of these data is given in Table 5. From these data, the point at which $50 \%$ of the females examined had at least one set of scars was found to occur at a head and body length of $197.7 \mathrm{~mm}$.

On these same 460 females, observations of pregnancy were made and in conjunction with placental scar observations, an analysis of the 
Table 3

Frequency distribution of number of embryos.

\begin{tabular}{lrrrrrrrrrrrrrrr}
\hline Number of Embryos & 1 & 2 & 3 & 4 & 5 & 6 & 7 & 8 & 9 & 10 & 11 & 12 & 13 & 14 & $\mathrm{X} \pm \mathrm{SD}$ \\
Incidence & 2 & 5 & 4 & 11 & 25 & 28 & 47 & 38 & 27 & 19 & 10 & 5 & 3 & 2 & $7.4 \pm 2.4$ \\
\hline
\end{tabular}

Table 4

Number of conspicuous mammae.

\begin{tabular}{|c|c|c|c|c|c|}
\hline $\begin{array}{l}\text { H \& B } \\
\text { Length }\end{array}$ & Sample & $\begin{array}{l}\text { Average } \\
\text { Number }\end{array}$ & $\begin{array}{r}\text { Conspicu } \\
\text { (Rang }\end{array}$ & $\begin{array}{l}\text { dous } \\
\text { (L+ } \\
\text { se in }\end{array}$ & $\begin{array}{l}\text { Mammae } \\
\text { R) } \\
\text { Pairs) }\end{array}$ \\
\hline $70-79$ & 1 & 0 & \multicolumn{3}{|c|}{ None } \\
\hline $80-89$ & 0 & - & \multicolumn{3}{|c|}{-- } \\
\hline $90-99$ & 2 & 0 & \multicolumn{3}{|c|}{ None } \\
\hline $100-109$ & 1 & 0 & \multicolumn{3}{|c|}{ None } \\
\hline $110-119$ & 5 & 5 & (None & - & $7 \times 7)$ \\
\hline $120-129$ & 5 & 1.2 & (None & - & $3 \times 3)$ \\
\hline $130-139$ & 10 & 4.1 & (None & - & $7 \times 7)$ \\
\hline $140-149$ & 9 & 2.4 & (None & - & $7 \times 5)$ \\
\hline $150-159$ & 7 & 8.7 & $(2 \times 2$ & - & $7 \times 7)$ \\
\hline $160-169$ & 25 & 7.4 & (None & - & $8 \times 9)$ \\
\hline $170-179$ & 48 & 9.0 & (None & - & $10 \times 9)$ \\
\hline $180-189$ & 78 & 11.8 & (None & - & $10 \times 9)$ \\
\hline $190-199$ & 135 & 14.7 & (None & - & $10 \times 10)$ \\
\hline $200-209$ & 183 & 15.5 & $(2 \times 2$ & - & $11 \times 11)$ \\
\hline $210-219$ & 165 & 15.9 & $(2 \times 3$ & - & $10 \times 10)$ \\
\hline $220-229$ & 92 & 16.1 & $(3 \times 4$ & - & $10 \times 9)$ \\
\hline $230-239$ & 41 & 16.5 & $(4 \times 5$ & - & $9 \times 9)$ \\
\hline $240-249$ & 10 & 16.4 & $(7 \times 8$ & - & $9 \times 10)$ \\
\hline
\end{tabular}

Table 5

Summary of observed placental scar sets.

\begin{tabular}{|c|c|c|c|c|c|c|c|c|c|}
\hline \multirow{2}{*}{$\begin{array}{l}\text { H \& B } \\
\text { Class }\end{array}$} & \multirow{2}{*}{$\begin{array}{c}\text { No. } \\
\text { Examined }\end{array}$} & \multicolumn{2}{|c|}{1 set } & \multicolumn{2}{|c|}{2 sets } & \multicolumn{2}{|c|}{3 sets } & \multirow{2}{*}{$\begin{array}{c}\text { Total with } \\
n\end{array}$} & \multirow{2}{*}{$\begin{array}{c}\text { scars } \\
\%\end{array}$} \\
\hline & & No. & $\%$ & No. & $\%$ & No. & $\%$ & & \\
\hline $110-119$ & 1 & 0 & 0 & 0 & 0 & 0 & 0 & 0 & 0 \\
\hline $120-129$ & 4 & 0 & 0 & 0 & 0 & 0 & 0 & 0 & 0 \\
\hline $130-139$ & 4 & 0 & 0 & 0 & 0 & 0 & 0 & 0 & 0 \\
\hline $140-149$ & 5 & 0 & 0 & 0 & 0 & 0 & 0 & 0 & 0 \\
\hline $150-159$ & 3 & 0 & 0 & 0 & 0 & 0 & 0 & 0 & 0 \\
\hline $160-169$ & 11 & 1 & 9.1 & 0 & 0 & 0 & 0 & 1 & 9.1 \\
\hline $170-179$ & 20 & 0 & 0 & 0 & 0 & 0 & 0 & 0 & 0 \\
\hline $180-189$ & 52 & 13 & 25.0 & 4 & 7.7 & 0 & 0 & 17 & 32.7 \\
\hline $190-199$ & 87 & 36 & 41.4 & 12 & 13.8 & 0 & 0 & 48 & 55.2 \\
\hline $200-209$ & 100 & 52 & 52.0 & 19 & 19.0 & 3 & 3.0 & 74 & 74.0 \\
\hline $210-219$ & 89 & 32 & 36.0 & 29 & 32.6 & 5 & 5.6 & 66 & 74.2 \\
\hline $220-229$ & 51 & 22 & 43.1 & 13 & 25.5 & 6 & 11.8 & 41 & 80.4 \\
\hline $230-239$ & 28 & 9 & 32.1 & 7 & 25.0 & 2 & 7.1 & 18 & 64.3 \\
\hline $240-249$ & 5 & 4 & 80.0 & 0 & 0 & 0 & 0 & 4 & 80.0 \\
\hline Total/Av. & 460 & 169 & 36.7 & 84 & 18.3 & 16 & 3.5 & 269 & 58.5 \\
\hline $\begin{array}{l}\text { Greater } \\
\text { than } 180 \mathrm{~mm}\end{array}$ & 412 & & 40.8 & & 20.4 & & 3.9 & 268 & 65.0 \\
\hline
\end{tabular}


number of litters produced. These data are shown in Table 6 . The number of females pregnant with a second litter was approximately half of the number pregnant with a first litter and the number of pregnant with a third litter was less than half that pregnant with the second. These data indicate a sharp decline in probability of multiple litter production.

Table 6

Litter production summary.

Numbers and percentages of pregnant females with consecutive litters are shown.

\begin{tabular}{|c|c|c|c|c|c|c|c|c|c|}
\hline \multirow{2}{*}{$\begin{array}{l}\mathrm{H} \& \mathrm{~B} \\
\text { class }\end{array}$} & \multirow{2}{*}{$\begin{array}{c}\text { No. } \\
\text { Examined }\end{array}$} & \multicolumn{2}{|c|}{ 1st litter } & \multicolumn{2}{|c|}{ 2nd litter } & \multicolumn{2}{|c|}{ 3rd litter } & \multicolumn{2}{|c|}{ 4th litter } \\
\hline & & $\mathrm{n}$ & $\%$ & $\mathrm{n}$ & $\%$ & $\mathrm{n}$ & $\%$ & $\mathrm{n}$ & $\%$ \\
\hline $110-119$ & 1 & 0 & 0 & 0 & 0 & 0 & 0 & 0 & 0 \\
\hline $120-129$ & 4 & 0 & 0 & 0 & 0 & 0 & 0 & 0 & 0 \\
\hline $130-139$ & 4 & 0 & 0 & 0 & 0 & 0 & 0 & 0 & 0 \\
\hline $110-149$ & 5 & 0 & 0 & 0 & 0 & 0 & 0 & 0 & 3 \\
\hline $15 ! ;--159$ & 3 & 0 & 0 & 0 & 0 & 0 & 0 & 0 & 0 \\
\hline $160-169$ & 11 & 1 & 9.1 & 0 & 0 & 0 & 0 & 0 & 0 \\
\hline $170-179$ & 20 & 3 & 15.0 & 0 & 0 & 0 & 0 & 0 & 0 \\
\hline $180-189$ & 52 & 7 & 13.5 & 0 & 0 & 2 & 3.8 & 0 & 0 \\
\hline $190-199$ & 87 & 17 & 19.5 & 8 & 9.2 & 1 & 1.2 & 0 & 0 \\
\hline $200-209$ & 100 & 10 & 10.0 & 11 & 10.0 & 6 & 6.0 & 0 & 0 \\
\hline $210-219$ & 89 & 16 & 18.0 & 6 & 5.6 & 5 & 5.6 & 1 & 1.11 \\
\hline $220-229$ & 51 & 9 & 17.6 & 8 & 15.7 & 2 & 3.9 & 0 & 0 \\
\hline $230-239$ & 28 & 8 & 28.6 & 5 & 17.9 & 1 & 3.6 & 0 & 0 \\
\hline $240-249$ & 5 & 1 & 20.0 & 2 & 40.0 & 0 & 0 & 0 & 0 \\
\hline Tot./Av. & 460 & 72. & 15.7 & 40 & 8.7 & 17 & 3.7 & 1 & 0.2 \\
\hline $\begin{array}{l}\text { Greater } \\
\text { than } 180 \mathrm{~mm}\end{array}$ & 412 & 68 & 16.5 & 40 & 9.7 & 17 & 4.1 & 1 & 0.2 \\
\hline
\end{tabular}

Table 7

Embryo counts/Litter by $\mathrm{H} \& \mathrm{~B}$ length class. (mean $\pm \mathrm{SD}$, range and number of observations).

\begin{tabular}{|c|c|c|c|c|}
\hline $\begin{array}{l}\mathrm{H} \& \text { \& B } \\
\text { length class }\end{array}$ & 1st litter & 2nd litter & 3rd litter & 4th litter \\
\hline $160-169$ & $4(1)$ & - & - & - \\
\hline $170-179$ & $6.7 \pm 2.3,4-8(3)$ & - & - & - \\
\hline $.80-189$ & $6.6 \pm 0.8,6-8(7)$ & - & $7.5,7-8,(2)$ & - \\
\hline $190-199$ & $6.6 \pm 2.1,3-10(17)$ & $5.6 \pm 2.1,2-8(8)$ & $9(1)$ & - \\
\hline $200-209$ & $7.1 \pm 1.6,5-9 \quad(10)$ & $8.2 \pm 2.9,5-13$ (11) & $8.0 \pm 2.3, \quad 4-10(6)$ & - \\
\hline $210-219$ & $7.6 \pm 2.2,4-11(16)$ & $8.8 \pm 1.5,7-10(6)$ & $9.6 \pm 2.7,6-13(5)$ & $12(1)$ \\
\hline $220-229$ & $6.8 \pm 2.1,3-10(8)$ & $6.6 \pm 2.2,2-9(8)$ & $8.0,5-11(2)$ & - \\
\hline $230-239$ & $8.4 \pm 2.3,4-11(8)$ & $8.6 \pm 3.2,6-14(5)$ & $6(1)$ & - \\
\hline $240-249$ & 7 (1) & $9.5,9-10(2)$ & - & - \\
\hline Means & $7.1 \pm 2.0$ & $7.6 \pm 2.6$ & $8.4 \pm 2.4$ & \\
\hline
\end{tabular}

From those data shown in Table 6, an analysis of the number of embryos in each litter (first, second, etc.) broken down by head and body length was prepared (Table 7). It was observed that the mean number 
of embryos increased with the number of litters produced and with the size of the female.

The observations made on seasonal reproductive activity, based on pregnancy and lactation, are presented in Figure 2. Each point was calculated as a three point running average. An average of $28.1 \%$ of the females captured each month were pregnant and $41 \%$ were either

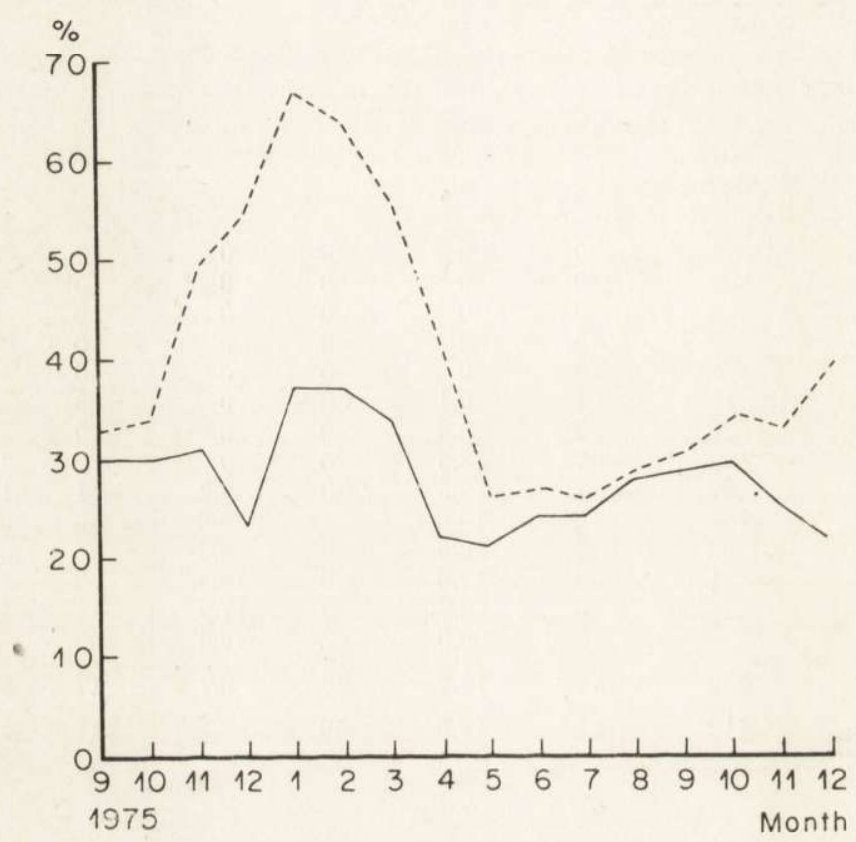

Fig. 2. Observations on pregnancy and lactation among female bandicoat rats for each month of the study period.

The solid line represents percentage of pregnant females observed each month and the dotted line the percent of females both pregnant and lactating during each month of the study.

pregnant or lactating. The correlation coefficient between the percent pregnant and the percent pregnant or lactating was 0.67 . This figure undoubtedly reflects the fact that our observations on lactation were incomplete. Nevertheless, the distinct peak from November through April reflects increased reproductive activity during this period. This period is characterized by mild temperature and very low rainfall.

Following the basic formula of Emlen \& Davis (1948) for the calculation of annual production $F=P(t / v)$ where

$P=$ the percent pregnant of female autopsy sample

$t=$ the time in days over which the sample was taken

$v=$ time in days during which embryos are visible 
The results show that 5.9 pregnancies per year per female occur with an average of $43 \pm 14$ embryos per year. The estimated average number of days between successive litters was 61.9 days.

\section{DISCUSSION}

The general range of head and body length and weight observed in this study are consistent with those observations previously recorded in Rangoon for $B$. bengalensis females by $\mathrm{H}$ arrison \& Woodville (1949). From those data reported by S p ill e t t (1966), female B. bengalensis in Calcutta are distinctly smaller than those in Rangoon. Although growth data for females were not extensive, S pille t t (1966) did note that females tended to grow faster than males. The significant shift in weight seen in Figure 1 at a head and body length of about $160 \mathrm{~mm}$ is most probably associated with sexual maturation. At this point, over $50 \%$ of the females captured in Rangoon had an open vaginal orifice (see Table 1), pregnancies were first detected (see Table 2) and females with placental scars were first observed (see Table 5).

The proportion of female bandicoots trapped by Spillett (1968) with perforate vagina orifices was slightly higher $(97.7 \%)$ than observed in Rangoon (96.7\%), but this difference cannot be considered significant. In Rangoon, no female below a head and body length of $110 \mathrm{~mm}$ exhibited an open vagina although Spillett (1968) found that $36 \%$ of those females of a head and body length of $100 \mathrm{~mm}$ or less had perforated vaginal orifices. This discrepancy is most likely related to the generally smaller size of $B$. bengalensis in Calcutta.

Of the total females captured in Calcutta grain godowns by $\mathrm{S} p$ ill e t $\mathrm{t}$ (1968), $51.2 \%$ were visibly pregnant. This greatly exceeds that observed $(27.5 \%)$ during this study. The fact that the animals captured in Rangoon were from a wide array of habitats may partially explain this difference in pregnancy rate. Another reason could be due to the high density bandicoot populations with which Spillett was dealing in the grain godown habitats. As we noted earlier, our data on lactation is suspect. Our observations agree with those of Spillett (1968) that milk could not always be expressed from mammae of females which dissection revealed were lactating. Data on lactation are included, albeit of limited value, in Table 2, however, for the purpose of completing the general reproductive picture. This problem of accurate detection of lactation undoubtedly influenced our observations on those females recorded as both pregnant and lactating. Estimates of the average number of days between successive pregnancies (30.5 to 34.4 days) among 
B. bengalensis females in Calcutta by Spillett (1968) indicated a post-partum: estrus and breeding. The same calculations for the $B$. bengalensis in Rangoon reveal that approximately twice (61.9 days) the number of days between successive pregnancies occur. Bearing in mind the deficiency in observations on lactation, the very low number of female $B$. bengalensis in Rangoon observed to be both pregnant and lactating, would tend to lend support to the idea that post-partum breeding is not a consistently significant aspect of the pattern of reproductive efforts of $B$. bengalensis in Rangoon.

We noted that there is an increase in the number of embryos per pregnant female as the size of the female increases. Spillett (1968) used much broader size categories $(50 \mathrm{~mm})$, but there appears to be general agreement on this aspect with our results. We noticed no decrease however, in embryo production among the larger or "older " females. Average litter size in Calcutta was reported as 6.2 embryos per female and the maximum number of embryos counted to be as high as 13 (S pillet t, 1968). The mean embryo count in Rangoon was $7.4 \pm 2.4$ and the maximum number of embryos observed was 14 (see Table 3 ).

Harrison \& Woodville $(1948,1949)$ noted the variability and asymmetery of the mammary pattern among $B$. bengalensis in Rangoon. Our observations are similar to theirs. It should be noted that although the conspicuousness of the mammae was related to whether the female was or had been pregnant, the number of mammae which were conspicuous appeared to be unrelated. Asymmetery was very common. The abundance of mammae (up to 11 pairs) is apparently unrelated to the number of embryos produced (avg. of 7.4). We do not know, however, if all conspicuous mammae are functional following parturition.

No previously published reports on placental scar data have been located. It appears from our observations that there are some female bandicocits which do not breed. This cannot be entirely accounted for by those which are immature. Slightly more than half $(52.4 \%)$ of the females examined had been or were pregnant with the first litter while more than a quarter $(27 \%)$ had been or were pregnant with the second litter. Only $7.2 \%$ had been or were pregnant with the third litter. A lone female had so many placental scars that four litters could be easily justified. Harrison \& Woodville (1950) speculated that in Rangoon the death rate of $B$. bengalensis was $67 \%$ per month. Spillet 1 (1966) noted that in Calcutta only rarely was an individual $B$. bengalensis recaptured three months after its initial capture. It would appear that the $B$. bengalensis population in Rangoon is maintained, in large measure, by the production of only one to two litters by the majority of breeding females. 
We did not see the decline in number of embryos with senescence indicated by Spillett (1968). Harrison \& Woodville's (1950) speculation on the mortality rate among bandicoots in Rangoon may well be quite accurate.

Reproduction of small mammal species in the tropics is under quite different influences than temperate climate species. In temperate regions, seasons are clearly marked by progressive fluctuations during the year in temperature and day length, with rainfall or snow occurring during certain well-defined periods. In the tropics, there is a much smaller fluctuation in annual temperature and day length but, still, seasonal changes are apparent. The dominant influence is rainfall, however, which can vary greatly from one area to another both in quantity and time of year when it falls (D e l a n y, 1972).

In Rangoon, $B$. bengalensis is primarily an outdoor-dwelling, burrowing species. Its burrow openings, soil mouds and numerous other evidences of its activities, such as collapsed sidewalks and blocked storm drain gutters, are abundant throughout the city. There is little evidence that it harbors indoors (except in grain storage warehouses and bazaars) as does Rattus norvegicus. During the monsoon rains therefore, its soil burrows could be expected to become quite damp, occasionally even flooded. We suspect that the monsoon rains exert an adverse effect upon breeding in this species, depressing not only pregnancy efforts and lactation, but also creating hardships on females with litters in burrow nests and on their young.

We noted a marked increase in reproductive activity, both pregnancies and lactation, during the dry season months from November to April. $B$. bengalensis in Rangoon, living outdoors and responsive to climatic influences, is thus a seasonal breeder, showing essentially a unimodal curve. Those data are not unlike those given by the Indian Plague Commission (summarized in Davis, 1953) for several populations of Rattus rattus in India (most notably Belguam and Bengal). Production of young in significant numbers is thus accomplished before the monsoon sets in, creating conditions that may be inamicable to weanlings and immatures. Reproduction (pregnancy) was observed throughout the study period, however, and it seems quite reasonable to suspect that young $B$. bengalensis enter the population continuously, with a peak of recruitment during the dry season.

It is interesting to speculate at this point on the impact of social behavior upon general reproductive patterns. The observations of physical conflict and chase-following described by Frantz (1973) as well as other density related factors might result in social trauma that either suppresses or stops normal reproductive patterns. These factors, 
however, are probably restricted to areas where high-density bandicoot populations occur.

Acknowledgements: The authors would like to express their appresiation to the Rangoon Health Divisian staff and the various Township Medical Officers whose cooperation made this study possible. Dr U Thaung, Deputy Director (Epidemialogy) provided valuable guidance to the entire work program of the Unit.

\section{REFERENCES}

1. Bhatnagar J. K., 1966: Role of rodents in plague epidemiology in Uttar Pradesh. Proc. Indian Rodent Symp.: 204-215. Calcutta, 1969.

2. Brooks J. E., Walton D. W., U Hla Naing, Daw San My int, U Maung Maung Tun, U Thaug \& Daw Ohn Kyi, 1977: Plague in small mammals and humans in Rangoon, Burma. Southeast Asian J. Trop. Med. Publ. Hlth., 8: $335-344$.

3. Davis D. E., 1953: The characteristics of rat populations. Quart. Rev. Biol., 28: $373-401$.

4. Delaney M. J., 1972: The ecology of small rodents in tropical Africa. Mammal Rev., 2: 1-42.

5. Deoras P. J., 1966: Significance of probable change of rat population in Bombay. Proc. Indian Rodent Symp.: 58-68. Calcutta, 1969.

6. E $11 \mathrm{erm}$ a n J. R., 1961: Fauna of India including Pakistan, Burma and Ceylon. Mammalia; Vol. 3, Rodentia, Pt. 2: 817-834. Zool. Survey India, Calcutta.

7. Emlen J. T. Jr. \& Davis D. E., 1948: Determination of reproductive rates in rat populations by examination of carcasses. Physiol. Zöol., 21: 59-65.

8. Frantz S. C., 1973: Behavioral ecology of the lesser bandicoot rat, Bandicota bengalensis (Gray), in Calcutta. Ph.D. Diss., Johns Hopkins Univ., School of Hyg. \& Pub. Health, Baltimore 222 p.

9. Harrison J. L. \& Woodville H. C., 1948: An attempt to control house rats in Rangoon. Trans. Roy. Soc. Trop. Med. Hyg., 42: 247-258.

10. Harrison J. L. \& Woodville H. C., 1949: Variation in size and weight of five species of house rats (Rodentia: Muridae) in Rangoon, Burma. Rec. Indian Mus., 49: 65-71.

11. Harrison J. L. \& Woodoville H. C., 1950: The growth of a tame specimen of the indian mole rat, Bandicota bengalensis (Rodentia: Muridae), and an attempt to estimate the age-structure of a wild population. J. Zool. Soc. India, 2: 14-17.

12. Se a 1, S. C. \& B a n erji R. N., 1966: Changing patterns of rodent population in Calcutta and Howrah. Proc. Indian Rodent Symp.: 69-83, Calcutta, 1969.

13. Spillett J. J., 1968: The ecology of the lesser bandicoot rat in Calcutta. Leaders Press Private Ltd: $1-223$. Bombay.

Accepted, April 28, 1978.

D. W. WALTON, J. E. BROOKS, U Maung Maung TUN i U Hla NAING

\section{OBSERWACJE AKTYWNOSCI REPRODUKTYWNEJ SAMIC BANDICOTA BENGALENSIS Z RANGUNU}

Streszczenie

W ciągu 15 miesięcy wylawiano $B$. bengalensis w mieście Rangun. U 826 samic zbadano kondycję rozrodezą, porównując ją z ciężarem i rozmiarami ciała. U samic 
nieciężarnych tempo przyrostu masy ciała na jednostkę długości raptownie wzrasta, kiedy zwierzę osiąga okolo $160 \mathrm{~mm}$ długości (Ryc. 1). U tej wielkości samic notowano pierwszą ciążę, stąd raptowny wzrost masy ciała związany jest z osiągnięciem dojrzałości płciowej. Wśród samic $z$ otwartą pochwą $50 \%$ stanowiły zwierzęta długości $132 \mathrm{~mm}$ (Tabela 1). Rozmiary samic karmiących przewyższały $180 \mathrm{~mm}$. Ilość embrionów, przypadających na 1 ciężarną samicę waha się $1-14$, średnio 7,4 (Tabela 2 i 3). Dorosłe samice mają od 0 do 22 gruczołów mlecznych, nieregularnie zgrupowanych. Pomimo, iż ich ilość i układ są wysoce zmienne rTabela 4) mogą one być przydatne w ustalaniu wielkości ciała zwierząt dojrzałych.

Po illości plam placentarnych i embrionów obliczono, że populacja w Rangunie istnieje dzięki produkcji $1-2$ miotów/samicę w ciągu życia. (Tabele 5 i 6). Analizie poddano także zależność między wielkością matki a ilością młodych $w$ kolejnych miotach (Tabela 7). Aktywność rozrodcza rozpatrywana w aspekcie sezonowym, osiąga szczyt $\mathrm{w}$ sezonie suchym $\mathrm{tj}$. między XI-IV. 